\title{
Among Greater Issues of the Day: Hong Kong in China, 2003-2013
}

Carolyn Cartier

\begin{abstract}
The geohistorical disjunctures between Hong Kong — colonial territory, global city, and special administrative region - and China challenge understandings of the relationship. Hong Kong officially maintains certain core values that differ from those of the People's Republic of China, while unofficial Chinese Communist Party united front activity in Hong Kong has arguably narrowed the range of the sayable, in Jacques Rancière's terms, in the public sphere. How does this admixture of core values, at turns antithetical and contested, appear in the space and time of Hong Kong? Interventions in the ideational dynamic between the city and the state, through images, utterances, performances, and alternative artworks, produce space for the appearance of subjects defined by the people. Not a postcolonial culture of disappearance but an ontology of politics where spaces of disagreement make apprehensible that which is politically unsayable. During the decade before the Umbrella Movement, in a fervent aesthetics of politics at the crossroads of hurtling urban transformation and accelerating illiberal governance, alternative art in Hong Kong populated social movement activity with claims on public space and the possibilities of the people in the sightlines of a democratic future.
\end{abstract}

Discursive realms under Chinese Communist Party (CCP) authority strive to represent China through relatable values in accessible language for strategic nationalism. Beginning in the mid2000s, after more than two decades of uneven economic development and rising inequality, the 
CCP turned to the "rhetoric of altruism" and a scripted harmonious society (hexie shehui, 和谐社 会) as the conceptual bases of its leadership. ${ }^{1}$ But China's official discourses receive mixed reception especially where ideational and value systems are not historically based on party orthodoxy, as in the Sinophone region of Hong Kong. ${ }^{2}$ The government of Hong Kong officially maintains certain core values that differ from those of the central government of the People's Republic of China (PRC). This historical condition moderates the notion of Chinese political culture and foregrounds dynamics that accommodate interpretation and negotiation. As a scholar of urban geography, I am interested in how these contested values become displayed in the life of the city and appear in the production of space.

Three events have recently come to mark differences between Hong Kong core values (Heong Gong hat sam gaa zik, 香港核心價值) and China's socialist core values (shehuizhuyi hexin jiazhi, 社会主义核心价值). The political fundamentals of the first one are well known. On 5 June 1989 one million people in Hong Kong marched in response to the violent suppression of protesters in Beijing. In 2003 broad-based activism against a plan to implement national security

${ }^{1}$ Gloria Davies, Worrying about China: The Language of Chinese Critical Inquiry (Cambridge, Mass., 2007), p. 69.

${ }^{2}$ See Shu-mei Shih, Visuality and Identity: Sinophone Articulations Across the Pacific

(Berkeley, 2007), p. 36. The regional concept, unbounded and multiscalar, connects places and publics. 
legislation in Hong Kong reset the baseline for latent concern about challenges to Hong Kong core values, as apprehensions associated with the transfer of sovereignty of the British colony of Hong Kong to the PRC in 1997 materialized six years later. ${ }^{3}$ The proximate cause of the third, allocation of public funds for a major railway in 2009, appeared to be the Hong Kong government's latest commitment to supply-side infrastructure development. But its technical distinctions - the world's costliest tunnel and largest underground station—resonated with "building big, with no regret," Zhu Tao's diagnostic of the socialist built environment in China since the 1950 s. ${ }^{4}$ Sustained, expansive opposition to the project's costs and impacts appealed to Hong Kong core values. ${ }^{5}$ How should interpretations of these events since 2003 be situated in Hong Kong?

${ }^{3}$ See Carole J. Petersen, "Hong Kong's Spring of Discontent: The Rise and Fall of the National Security Bill in 2003," in National Security and Fundamental Freedoms: Hong Kong's Article 23 Under Scrutiny, ed. Fu Hualing, Petersen, and Simon N. M. Young (Hong Kong, 2005), pp. 13-62, and Ngok Ma, "Civil Society in Self-Defense: The Struggle Against National Security Legislation in Hong Kong," Journal of Contemporary China 14 (Aug. 2005): 465-82.

${ }^{4}$ See Tao Zhu, "Building Big, with No Regret,” AA Files 63 (2011): 104-10.

${ }^{5}$ See Chor-yung Cheung, "Hong Kong's Systemic Crisis of Governance and the Revolt of the 'Post-80s' Youths: The Anti-Express Rail Campaign," in New Trends of Political Participation in Hong Kong, ed. Joseph Y. S. Cheung (Hong Kong, 2014), pp. 417-47, and Sui Ming Tsang, "A Philosophical Analysis on the Reasons Against the Building of the Guangzhou-ShenzhenHong Kong Express Rail Link," in Ethical Dilemmas in Public Policy: The Dynamics of Social 


\section{Culture of Disappearance or Ontology of Politics?}

Analysis of the relationship between Hong Kong and mainland China has tended to highlight political differences arising in the space of twentieth-century geopolitics and the moment of 1997. ${ }^{6}$ This dominant viewpoint internalizes the condition of late colonialism in Hong Kong without independence. It tends to influence critique as if culture and politics are always already framed. For instance, Ackbar Abbas conceptualizes "a culture whose appearance is accompanied by a sense of the imminence of its disappearance," which does not see what $i$ s there. ${ }^{7}$ This refusal to see and reverse hallucination rests in "a gap or hysteresis between the city and its representations," whose formation, in binary tropes (East/West, tradition/modernity), unstable local icons (harbor junks, shophouses), and colonial conceits (compradore mentality, "cultural desert"), reflects how Hong Kong, ever iconic, has been shaped by the powers of metropoles-

Values in the East-West Context of Hong Kong, ed. Betty Yung and Kam-por Yu (Singapore, 2016), pp. 167-82.

${ }^{6}$ Mirana May Szeto evaluates this dominant viewpoint in the "'1997 factor"” and Hong Kong “'in-between two colonizers"'; see Mirana May Szeto "Intra-local and Inter-local Sinophone: Rhizomatic Politics of Hong Kong Writers Saisai and Wong Bik-wan,” in Sinophone Studies: A Critical Reader, ed. Shu-mei Shih, Chien-hsin Tsai, and Brian Bernards (New York, 2013), p. 191.

${ }^{7}$ Ackbar Abbas, Hong Kong: Culture and the Politics of Disappearance (Minneapolis, 1997), p. 71; hereafter abbreviated $H K$. 
London and Beijing - beyond its control, limiting its potential to become one among global cities $(H K$, pp. 71, 6).

The reality of Hong Kong reverting to Chinese sovereignty with liberal public institutions is a particular case, as Abbas identifies it, of "a postcoloniality that precedes decolonization" (HK, p. 6). Approaches that would interrelate Hong Kong and mainland China stall in realization of territorial displacements and discrepant modernities. ${ }^{8}$ Comparative space-time relations seem out of synch. The CCP became the ruling regime of China in 1949 and projects its sovereign authority back as well as forward in time; it claims to represent five thousand years of dynastic history but has yet to govern Hong Kong directly. ${ }^{9}$ Narratives of place, political economy, and national belonging tremble to align. A British colony from 1842-1997, Hong Kong is a special administrative region (SAR) and province-level administrative territory of the PRC until July 2047. In the PRC's unitary political system, Hong Kong is defined in relation to a party state formulation (tifa, 提法), “one county-two systems” (yiguo liangzhi, 一国两制), but the CCP maintains power to reinterpret its meaning. ${ }^{10}$ Nevertheless, Hong Kong is a separate statistical

${ }^{8}$ See Lisa Rofel, "Discrepant Modernities and Their Discontents," positions 9 (Winter 2001): 637-49.

${ }^{9}$ The historical claim is contested because many borderland regions including south China were subject to colonizing military conquests. Shu-mei Shih refers to "continental colonialism" in "Introduction: What is Sinophone Studies?” in Sinophone Studies, pp. 1-16.

${ }^{10}$ Michael Schoenhals analyzes party formulations in Doing Things with Chinese Words (Berkeley, 1992). 
entity in the world economy. The 2016 United Nations Human Development Index ranks Hong Kong number twelve behind Canada and the US (tied) and above New Zealand and Sweden. ${ }^{11}$ Such incommensurabilities — pressed into imaginaries of geopolitical space — contribute to the artificial condensation of politics and culture, with tendencies to coalesce in what Jacques Rancière calls "postdemocracy."12 Postdemocracy and its harmonious-sounding variant, consensus democracy, trade the politics of representation for recognition and countability, valorizing identity in façade-managed maldistributions of political and economic power. "In a space of disappearance," Abbas writes, "caught between two colonialities . . . there is a desperate attempt to clutch at images of identity" (HK, p. 69). Evanescence revs up nostalgia. Abbas finds a culture of disappearance especially expressed in Hong Kong cinema, building on the spacetime variability within the film medium. "The danger," Ban Wang observes, is that "cinema works easily as a symbol of the contemporary global regime of simulacra rather than its

${ }^{11}$ China ranks number ninety in Selim Jahan et al., Human Development Report 2016: Human Development for Everyone (New York, 2016), p. 199, hdr.undp.org/sites/default/files/2016_human_development_report.pdf 12 Jacques Rancière, Disagreement: Politics and Philosophy, trans. Julie Rose (Minneapolis, 1999), p. 101; hereafter abbreviated D. Harry Harootunian argues that both cultural studies and area studies have worked in an "effective separation of politics and culture" that favors politics of identity over democratic politics (Harry Harootunian, “Theory’s Empire: Reflections on a Vocation for Critical Inquiry," Critical Inquiry 30 [Winter 2004]: 401). 
critique." ${ }^{13}$ Situating postdemocracy's police order - the distribution and partition of the visible and the sayable that precludes actual politics-Rancière writes, "it is not a matter of art and taste [confronting Bourdieu]; it is ... a matter of time and space.... as forms of configuration of our 'place' in society." ${ }^{14}$ The disappearance concept itself, pacing the run-up to 1997 , internalizes a liminal aesthetics with temporal limits. Its before and after binary, indexing two national powers, consolidates a dominant hierarchical imaginary. It does not anticipate rhizomatic affinities, as Mirana May Szeto finds, that "open up intra-local, subaltern sensitivities to accommodate the greater issues of the day." ${ }^{15}$ The optic of disappearance arguably did not see what was already there: the potential of a political movement in Hong Kong challenging socialist core values.

\section{Contending Core Values}

In the relationship between Hong Kong and mainland China, aesthetics of politics contend to frame core values, power relations, and authority through expressions of exemplarity. ${ }^{16}$ China's socialist core values have expanded in recent years while some are more established than

${ }^{13}$ Ban Wang, Illuminations from the Past: Trauma, Memory, and History in Modern China (Stanford, Calif., 2004), p. 206.

${ }^{14}$ Rancière, "From Politics to Aesthetics?" Paragraph 28 (Mar. 2005): 13.

${ }^{15}$ Szeto, “Intra-local and Inter-local Sinophone," p. 193.

${ }^{16}$ The history of exemplarity in China transcends political regimes; see Børge Bakken, The Exemplary Society: Human Improvement, Social Control, and the Dangers of Modernity (New York, 2000), and Davies, Worrying about China, pp. 15-57. 
others. ${ }^{17}$ Harmony first gained prominence in 2005 when it became the party state's leading concept in relation to scientific development and discourse about civil society. ${ }^{18}$ It was incorporated into the national Eleventh Five-Year Plan (2006-2010) to evoke socioeconomic equality and subsequently entered near-ubiquitous circulation. It also became an action verb whose objects the state seeks to neutralize: harmonious society is an ideal whose attainment depends on, among other governing capacities, harmonization or censorship. ${ }^{19}$ Meanwhile, netizens transmuted the official watchword into its parodic homonym, river crab (hexie, 河蟹). When authorities targeted for destruction Ai Weiwei's Shanghai studio in 2010, Ai invited guests for a feast of river crabs to bid farewell to the building. However, it was not funny. The state media organ, Xinhua News, authoritatively warns that joking is inconsistent with socialist core values. $^{20}$

${ }^{17}$ The CCP articulated a set of twelve socialist core values at the Eighteenth Party Congress in 2012; see Michael Gow, "The Core Socialist Values of the Chinese Dream: Towards a Chinese Integral State," Critical Asian Studies 49, no. 1 (2016): 92-116.

${ }^{18}$ See Yu Keping, Democracy is a Good Thing: Essays on Politics, Society, and Culture in Contemporary China (Washington, D.C., 2009).

${ }^{19}$ See Xiao Qiang, "Liberation Technology: The Battle for the Chinese Internet," Journal of Democracy 22 (Apr. 2011): 47-61.

${ }^{20}$ See Mark Magnier and Lillian Lin, “April Fools' Day is 'Inconsistent with Core Socialist Values,' Chinese News Agency Says," The Wall Street Journal, 1 Apr. 2016, 
Systematic articulation of socialist core values is the work of the Propaganda Department (Xuanchuan bu, 宣传部), a bureaucracy under the CCP Central Committee. Its official Englishlanguage translation changed in 2008 to the Publicity Department, which evinces how the Leninist state has embraced consumer capitalism and its aesthetics of diversity. The propaganda system's portrayal of the keywords of socialist core values demonstrates uniform structure in different styles. Traditional red and yellow colors of party symbolism contrast with popular versions in green tones with leafy trees and shining sun (figs. 1-2). The uniformity of the design in three tiers, state, society, and the people, replicates traditional state-society organization. Harmony appears in the top tier as a national or central value, side by side with prosperity, democracy, and civilization. Democratic centralism within Chinese socialism, in which questioning CCP policy and programs takes place substantively only within party ranks, allows the PRC to include democracy among its socialist core values. ${ }^{21}$ Freedom, equality, justice, and rule of law, in the second or societal tier, indicate their subjection to party policy and decisionmaking; for example, they are not defined on the basis of rights. Similarly, the PRC has not adopted separation of governing powers. In other words, the core political concept of the Chinese

blogs.wsj.com/chinarealtime/2016/04/01/april-fools-day-is-inconsistent-with-core-socialistvalues-chinese-news-agency-says/

${ }^{21}$ See Stephen C. Angle, "Decent Democratic Centralism," Political Theory 33 (Aug. 2005): 518-46, and Steve Tsang, "Consultative Leninism: China’s New Political Framework," Journal of Contemporary China 18 (Nov. 2009): 865-80. 
state is its self-arrogated authority. ${ }^{22}$ Nevertheless, the keywords resonate with Western notions about global values, evoking an aspirational citizenship.

Though the word core appears in party thought across the decades, its representative aesthetic has changed in recent years. Mao Zedong used core to describe the role of the CCP. ${ }^{23}$ In the post-Mao era it represents party leadership; in 2016 the CCP affirmed a new title, "core leader" (hexin lingdao, 核心领导). ${ }^{24}$ As if the word has become flesh, intensifying the personification of affirmative power, core has become a synecdoche for the chairman of the CCP. One version of its aesthetic, produced at Harvard University, depicts the elemental meaning of

\footnotetext{
${ }^{22}$ Party-state authority governs that which the state deems to be inharmonious through stability maintenance [weiwen, 维稳] Please see commnet 4 above (Yuhua Wang and Carl Minzner, “The
} Rise of the Chinese Security State," The China Quarterly 222 [June 2015]: 339-359). ${ }^{23}$ The first instance, which has become a quotation in Mao Zedong thought, is from a speech in which Mao states, "The Chinese Communist Party is the core of the leadership of the entire Chinese people; without such a core, the cause of socialism cannot be victorious;" see “Quotations from Mao Tse Tung,” Marxists.org, www.marxists.org/reference/archive/mao/works/red-book/ch01.htm 24 中国共产党第十八届中央委员会第六次全体会议公报 (Communique of the Sixth Plenary Session of the Eighteenth Central Committee of the Communist Party of China), Please see comment 5 above. People.cn, 27 Oct. 2016, cpc.people.com.cn/n1/2016/1027/c6409428814120.html 
core (he, 核), the spatial center of an object, and, apparently, as a nucleus (hexin, 核心), the modern scientific meaning (fig. 3). This infographic is interesting because it reorients the regular illustration of the CCP leadership, at the apex of a top-down flow chart, to the center of a circular object as if at the center of a representative totality. ${ }^{25}$

A comparison of socialist core values and Hong Kong core values shows significant differences. The Hong Kong governing system, based on liberalism including rule of law and freedom of speech, maintains core values that its chief executive vows to uphold: "Human rights, rule of law, clean government, freedom and democracy, tolerance of different stances and views, and respect for press freedom." ${ }^{26}$ Together, they demonstrate a basis in individual rights and freedoms, including academic freedom, and separation of powers. They are articulated in the Basic Law of Hong Kong, promulgated under the authority of the Chinese central government. ${ }^{27}$ Most of the Hong Kong core values are not mirrored in socialist core values.

25 The illustration also suggests how international institutions become involved in reproduction of CCP thought. W. J. T. Mitchell develops the as-if construction in What Do Pictures Want? The Lives and Loves of Images (Chicago, 2005), p. 7.

${ }^{26}$ Office of the Chief Executive, "Upholding the Core Values of Hong Kong," www.policyaddress.gov.hk/2013/eng/p197.html. The core values of Hong Kong appear in the Policy Address of the Chief Executive of the Hong Kong SAR.

${ }^{27}$ See Yash Ghai, Hong Kong's New Constitutional Order: The Resumption of Chinese Sovereignty and the Basic Law (Hong Kong, 1999). 
One core value apparently shared between Hong Kong and mainland China is democracy. Its inclusion in the top tier of socialist core values can be read within PRC core leadership and postdemocracy. Its existence affords the party state a discursive basis of asserting leadership through supposedly common values. The party's work on a "new people's democracy" through "core points" now asserts the superiority of "socialist democracy with Chinese characteristics." 28 Postdemocracy, in debate across the political-economic spectrum, appears in these sightlines. "Postdemocracy is not a democracy that has found the truth of institutional forms," Rancière writes: "It is an identifying mode, among institutional mechanisms, and the allocation of the society's appropriate parts and shares, for making the subject and democracy's own specific action disappear" (D, p. 102).

\section{Publics, Freedoms, and the Press}

In 2004 a group of three hundred professionals - representing those who have an established part in the prevailing order - published the Hong Kong Core Values Declaration. It appeared in newspapers on 7 June 2004, the Monday after 4 June, which remembered the Tiananmen massacre and the place of Hong Kong in China. (Alone in China, Hong Kong publicly

${ }^{28}$ The "new people's democracy" also adopts a discourse of rights, as in "the West has no right to monopolize the “democratic state’ standard” (韩震 [Han Zhen], “韩震中国才是当今世界最 大的民主国家 [China is the Largest Democratic State in the Contemporary World], " Please see comment 8 above Qiushi, 15 Nov. 2017, www.qstheory.cn/dukan/qs/201711/15/c_1121947684.htm). 
commemorates the massacre.) The declaration, stating concerns about erosion of democracy, human rights, rule of law, social justice, and integrity and transparency, contributed to establishing a narrative of solidarity. ${ }^{29}$ Its recursive articulation of Hong Kong core values responded to events of 2003. That year the attempt to implement national security legislation, which would accommodate increased state surveillance, galvanized Hong Kong publics. ${ }^{30}$ Opposition to it materialized in half a million participants in the 1 July march, which marks the anniversary of Hong Kong becoming the SAR. It was the largest demonstration in Hong Kong since the spontaneous one that took place on 5 June 1989. Its size had effects, quashing immediate pursuit of the legislation.

The appearance of socialist core values in Hong Kong and responses to them take diverse forms, from mundane and repetitive, subtle and coded, to ironic, ludic, and spectacular. They vary situationally and often appear in relation to United Front work. Like the Propaganda Department, the United Front Department is a party organization under the CCP Central Committee. The Chinese word for united front, tongzhan (统战), is short for tongyi zhanxian (统

${ }^{29}$ See Carol A. G. Jones, Lost in China? Law, Culture and Identity in Post-1997 Hong Kong (Cambridge, UK, 2015), p. 36.

${ }^{30}$ Article 23 of The Basic Law states that the SAR will enact security legislation but does not clarify of what kind and in what ways. See Petersen, "Hong Kong's Spring of Discontent," pp. 13-62, and Ngok Ma, "Civil Society in Self-Defense," pp. 465-82. 
一战线) or "united battle front." ${ }^{31}$ It is based in Hong Kong at what is formally called the Liaison Office of the Central People's Government in the Hong Kong Special Administrative Region. The United Front office carries out extensive yet informal, semicovert, and sequestered activity to build receptivity to the party's values and goals. ${ }^{32}$ Its successful work depends on acceptance of CCP leadership by social and economic elites. One of its main forms of activity is committee work on policy and planning for Hong Kong. Committee members and participants may not disclose proceedings. ${ }^{33}$ The semicovert nature of United Front activity means that direct dialogue over its policies or with its representatives does not take place — narrowing the range of the sayable. In this context of absence, the Hong Kong core-values discourse constitutes a narrative basis of rhetorical transaction. Its representations and interpretations, among what groups, in relation to what audience or publics, and with what effects or results, arguably become represented ever more acutely through symbolic forms and an aesthetics of politics.

Contradictions between the harmony of the PRC's socialist core values and freedoms of the press and speech in Hong Kong's core values have become visible in diverse ways. These include documentation of increased incidents of violence toward members of the press, new

${ }^{31}$ Barmé, "The Battle Behind the Front," China Heritage, 25 Sept. 2017, chinaheritage.net/journal/the-battle-behind-the-front/

${ }^{32}$ See Christine Loh, Underground Front: The Chinese Communist Party in Hong Kong (Hong Kong, 2010), p. 13.

${ }^{33}$ See Wai-kwok Wong, "Can Co-optation Win Over the Hong Kong People? China's United Front Work in Hong Kong Since 1984," Issues \& Studies 33 (May 1997): 104, 126. 
limitations on access to historically public information, and requests from the Liaison Office to "improve" coverage of mainland China. ${ }^{34}$ Pressure on press freedom has also become apparent in unpredictable ways through individual instances of censorship. For example, a Hong Kong newspaper deletes an article whose subject apparently flags the interest of the censorate. In 2011 the South China Morning Post, Hong Kong's largest English-language daily, deleted "Grateful Ai Weiwei Praises Hong Kong's Role," which appeared Saturday, 25 June. It was on the website for less than two days. ${ }^{35}$ Its topic was notable because the conditions of Ai's bail (qubao houshen, 取保候审) specified that he could express gratitude (biaoda xieyi, 表达谢意). ${ }^{36}$

${ }^{34}$ The Hong Kong Journalists Association, "Shrinking Margins: Freedom of Expression in Hong Kong since 1997, 2007 Annual Report,” www.hkja.org.hk/ebook/e_Annual_report_2007/mobile/index.html (AUTHOR: New link, and "Dark Clouds on the Horizon: Hong Kong's Freedom of Expression Faces New Threats, 2013 Annual Report,” www.hkja.org.hk/ebook/e_Annual_report_2013/mobile/index.html (AUTHOR: new link)

${ }^{35}$ On 27 June 2011 I telephoned the archive of the South China Morning Post and was told that a decision had been made not to keep the article.

${ }^{36}$ Such specificities reflect a provision in Chinese law that allows officials to set conditions of release (Jerome Cohen, personal communication, 11 July 2011). See also Siweiluozi, "How to Translate 取保候审: A Modest Proposal, ”Siweiluozi’s Blog, 23 June 2011, www.siweiluozi.net/2011/06/how-to-translate-modest-proposal.html 
The article reported a brief exchange. Ai told the paper, "I was aware that many people in Hong Kong have appealed for and supported my release. I'm very touched by that. We Chinese should head towards being more open and reasonable, which is the indicator of an advanced society. Hong Kong is the model of being open and reasonable." ${ }^{37}$ Ai expressed gratitude but not, apparently, as intended. He expressed gratitude to a place, a territorial space of the nation transformed by human meaning. His words positioned Hong Kong as the representative place of exemplarity. The word model (dianxing, 典型 or moshi, 模式) is a keyword in China's propaganda lexicon in which didactic models, as model citizens and model cities, circulate to govern human conduct and urban development. ${ }^{38}$ In the territorialadministrative hierarchy, Hong Kong is necessarily a lower-tier object of integration and cooperation (yiti hezuo, 一体合作). Treating Hong Kong as the model of the advanced upends the hierarchy, challenging party state authority.

Ai was detained in Beijing Capitol International Airport on 3 April 2011. Within days, stenciled images of Ai's likeness appeared around Hong Kong, on walkways, walls along alleys, the occasional doorway. Stencil templates, available online, became a DIY opportunity (figs. 4a

37 “Grateful Ai Weiwei Praises Hong Kong’s Role,” South China Morning Post, 25 June 2011. ${ }^{38}$ See Bakken, The Exemplary Society, pp. 211-42, and Carolyn Cartier, "Exemplary Cities in China: The Capitalist Aesthetic and the Loss of Space," Eurasian Geography and Economics 60 (Sept. 2019): 376-99. Christian Sorace identifies how Ai's work reveals the party's discursive limitations; see Christian Sorace, "China's Last Communist: Ai Weiwei," Critical Inquiry 40 (Winter 2014): 401. 
and 4b). Most included the caption, "Who's Afraid of Ai Weiwei?" The images proliferated from backstreets to the central business district. Headlines like "Who Visits Whom: I'd Really Like to Give Mainlanders and Bankers a Look at My Graffiti," in the Chinese-language press, suggested why the ensuing police investigation escalated — graffiti is a misdemeanor in Hong Kong but the case was assigned to the felony crime unit. ${ }^{39}$ In the core business districts, the image introduced dissensus to the landscape, as if a live transversal angling across identities and hierarchies of consensus democracy. ${ }^{40}$ The "graffiti girl" who launched the campaign explained: "I'm not very politically sensitive normally, but this really touched some core values-there's a line that should not be crossed." ${ }^{.41}$ Her statement repositioned core values as a basis of citizen subjectivity and political participation.

The 18 April edition of the Hong Kong Economic Journal (信報財經新聞) published a discussion of the case of Ai and broader arguments on the relationship between art and democracy, the idea of the artist as a citizen, and the potential of citizen action in pursuit of

${ }^{39}$ See 葉寶琳 (Ye Bolin), “什麼人訪問什麼人: 與塗鴉少女對談”

(Who Visits Whom: I'd Really Like to Give Mainlanders and Bankers a Look at My Graffiti), Ming Pao, 24 Apr. 2011, www.inmediahk.net/什麼人訪問什麼人: 與塗鴉少女對談

${ }^{40}$ See Rancière, Dissensus: On Politics and Aesthetics, trans. and ed. Steven Corcoran (New York, 2010), p. 38.

41 “Ai's Arrest Crossed a Line, Says Graffiti Artist," South China Morning Post, 16 Apr. 2011, www.scmp.com/article/965198/ais-arrest-crossed-line-says-graffiti-artist 
equality. It located overreaction to proliferation of the image "as if Ai Weiwei has touched the 'red line' of the CCP," in the party state's fear of social movements. ${ }^{42}$ (Events of the Arab Spring were concurrently unfolding on the other side of the hemisphere.) Circulating online, bloggers and commentators responded, with quotes from and references to Rancière's thought. ${ }^{43}$ Rancière's renown in the Sinophone region of Hong Kong and Taiwan expanded after 2009 when he gave lectures in Taiwan. Chinese editions of The Future of the Image and Disagreement appeared in 2011. Even Wen Wei Po (文匯報), state-owned organ of the Liaison Office, reviewed 歧義 (Qiyi or ambiguity), the Chinese title of Disagreement. ${ }^{44}$

On Saturday, 23 April 2011, Art Citizens (藝術公民) marched down Nathan Road to the Cultural Centre at the Kowloon waterfront. Leading the way was a replica of the grass mud horse (cao ni ma, 草泥马) that Ai had made for a 2009 artwork (fig. 5). The grass mud horse, a homonym of cao ni ma (窉你妈 or fuck your mother), and close companion of the river crab, is a ${ }^{42}$ The original adopts an “as if” construction: “恍如艾未未觸及中共“紅線” ” in “民主對藝術的 挑戰: 艾未未事件的還原思考 (The Challenge of Democracy to Art: Reflections on the Case of Ai Weiwei),”信報財經新聞 (Hong Kong Economic Journal), 18 Apr. 2011, forum.hkej.com/node/66417

${ }^{43}$ A basic search of Rancière and Hong Kong in Chinese returns some one million results. ${ }^{44}$ See 彭礪青 (Peng Liqing), “書評: 超越‘共識”的聲音” (review of Disagreement by Ranciére), Wen Wei Po (文匯報), 27 June 2011, paper.wenweipo.com/2011/06/27/OT1106270013.htm (AUTHOR: added) 
distinctive punning response to censorship by the party state that anthropomorphizes its sovereign territory as the motherland. The fantastic creature, appearing like a llama/alpaca coated in a quantity 1970s-era off-white shag carpet, trundled along on a rolling platform. Its height, visible at a distance, forged contact with the crowd. Kacey Wong, who had organized Art Citizens in response to increased censorship, pulled his sculpture by a rope tied around its neck. Accompanied by Chin Tangerine, nom de stencil, he spoke to the press. Chin Tangerine said: “This isn't about artists or politicians, it's about everyone ... because we have a fair judicial system and the right to freedom of speech, it's our responsibility to speak out." Wong continued: "This kind of disappearance could be a foreshadowing of what is to come." $" 45$ (Ideas about a culture of disappearance, in knowing what is there, gained proportionate meaning.) In apparent response, the May edition of Bauhinia magazine, organ of the Liaison Office in Hong Kong, published a Cultural Revolution-era style denunciation, "The Life and Times of Ai Weiwei," which foregrounded a "choice about values" bent on "destroying" China's "5,000-year-old

45 “Hundreds March in Support of Detained Artist Ai Weiwei," South China Morning Post, 24 Apr. 2011, www.scmp.com/article/965919/hundreds-march-support-detained-artist-ai-weiwei 
cultural tradition." ${ }^{46}$ Art Citizens' action culminated in “Love the Future, 爱未来,” a month-long exhibit featuring sculpture, installation, photography, performance, and poetry. ${ }^{47}$

\section{Space-Time, Image, and Artwork}

Images and texts portray and transpose relations among places. A relational concept of human geography conceptualizes place in spatial relations and variation in spatial relations among

places. ${ }^{48}$ In a dialectic of space-time, images and artworks and images of artworks contribute to contingent meanings of place and challenge spatial relations. The potential of an aesthetics of politics to intervene and redistribute the sensible, working through "spaces and times, subjects and objects, the common and the singular," may make new arrangements for what can take

${ }^{46}$ Siweiluozi assesses the 紫荆 (Zijing), or Bauhinia essay, in “The Vituperative Mode of Chinese Criticism: 'The Life and Times of Ai Weiwei,"' Siweiluozi’s Blog, 28 May 2011, www.siweiluozi.net/2011/05/vituperative-mode-of-chinese-criticism.html ${ }^{47}$ The exhibition's romanized Chinese name, ai weilai, means “loves Weiwei.” See 爱未来一 Love the Future, ed. Kacey Wong (exhibition catalog, Art Island East, Hong Kong, 26 May-26 June 2011) and Wong, “Love the Future Art \& Poetry Exhibition 爱未来,” www.youtube.com/watch?v=I8MmINzAdzc ${ }^{48}$ See Eric Sheppard, "David Harvey and Dialectical Space-Time" in David Harvey: A Critical Reader, ed. Noel Castree and Derek Gregory (Malden, Mass., 2006), pp. 121-41. 
place. ${ }^{49}$ Another sensible world emerges 'in transforming this space of 'moving-along,' of circulation, into a space for the appearance of a subject: the people, the workers, the citizens."

The annual 1 July march is a space of moving along as well as a mobile site for the potential of politics that redistributes what can take place. In 2004 it became a site for the performance of Hong Kong core values though multiple media artworks. In A Present to the Central Government: The Yellow Ribbons, realized as a video, Pak Sheung-cheun bridged the distance between Hong Kong and the central government. ${ }^{51}$ Pak brought to Beijing ribbon strips from a length of yellow cloth, which, originally placed across the path of the march, had been stamped with footprints denoting the right to demonstrate. In the core of the capital, on a circuit of the Forbidden City, he tied them to a pedestrian guardrail here, a signpost there. The project linked the public space of citizen participation in the Hong Kong SAR with the nation-space of authority, in a circumambulation that effectively requested an audience. The next year authorities barred a screening of The Yellow Ribbons at the 2005 Guangzhou Triennial. ${ }^{52}$

${ }^{49}$ Rancière, Aesthetics and Its Discontents, trans. Corcoran (Malden, Mass., 2009), p. 25. Please see comment 13 above

${ }^{50}$ Rancière, Dissensus, p. 37.

${ }^{51}$ In 2005, Para/site Art Space featured The Yellow Ribbons in "Power Plays," an international exhibit of political performance and video works.

${ }^{52}$ See Jaspar K. W. Lau, "No 'Local' is an Island," Yishu: Journal of Contemporary Chinese Art 5 (June 2006): 90. 
Another performance in the 2004 march, Wedding Engagement at the July 1 Protest, by Clara and Gum, founders of $C \& G$ Artpartment, resulted in a striking image that circulated widely in the Hong Kong media (fig. 6). Believing "good performance art can arouse people's interest in politics," Clara and Gum were engaged to be married while on the march. ${ }^{53}$ Representing fidelity and unity, and symbolizing trust, honesty and caring, their timeless commitment resonated in the face of heightened concern over whether the central government would maintain its historic commitment, articulated in The Basic Law, to support Hong Kong core values. Their traditional Chinese wedding clothes, demonstrating a sense of transcendent identity, closed the distance between just moving along and space for rearticulating meanings of unity and community. In space-time, Wedding Engagement at the July 1 Protest suggests what Judith Butler identifies as the performative force that results from the reproduction of conventional acts in nonconventional spaces and times. ${ }^{54}$ It suggests Rancière's way of seeing how imagery can convey a narrative of shared history, implicitly symbolizing sources of disunity and incomprehension elsewhere. ${ }^{55}$

Distinctive performance works in space-time relations also appeared in the 2007 march, marking the tenth anniversary of the Hong Kong SAR. Leung Po-shan, scholar and artist,

${ }^{53}$ Gum Cheng Yee-man, "How Can Performance Art Play a Role in Political Movements," South China Morning Post, 17 July 2005, paddle8.com/work/cheng-yee-man-gum/41646-southchina-morning-post-17-july-2005/

${ }^{54}$ See Judith Butler, Excitable Speech: A Politics of the Performative (New York, 1997), p. 147.

${ }^{55}$ See Rancière, The Future of the Image, trans. Gregory Elliott (New York, 2007), p. 26. 
reflected on the passing of time with an outlook on "sovereignty without decolonization as a long journey backwards. ${ }^{\prime 56}$ Leung walked backwards the full length of the march. A group project to write banners to carry in the march, "Among Others," united Hong Kong and mainland artists. Tobias Berger, director of Para/Site Art Space, and Shu Yang, founder of China's DaDao Live Art Festival, cocurated the activity. Their conceptual departure adopted a dose of exemplarity in Hong Kong as "the accelerating agent for Chinese democracy." Tea Takes the Street" by Pak, in reference to hybridity in Hong Kong tea-drinking habits, and "Refuse to Forget 1989" by "anonymous," a portrayal of self-censorship. After the march the banners were hung at Para/Site. The one draped across the façade was “我恨这个党! I hate this party!" in eponymous reference to the regime and a troubled time for Hong Kong core values (fig. 7).

Distribution and redistribution of the sensible exists within the space-time of aestheticpolitical regimes. Strategic placement of imagery, as an interruption, a cipher or a call, may contribute to revising the sensory landscape, redistributing the sensible for a new play. ${ }^{58}$ But the introduction of artwork to the urban scene promises no scenario of cause and effect. Did the

${ }^{56}$ Quoted in Cartier, "Power Plays: Alternative Performance Art and Urban Space in the Political Life of the City," in Hong Kong Culture: Word and Image, ed. Kam Louie (Hong Kong, 2010), p. 37. The exhibition "Talkover/Handover," developed by the Asia Art Archive and 1a space, collected artists' responses to the decade.

${ }^{57}$ Quoted in ibid.

${ }^{58}$ See Rancière, The Future of the Image, pp. 24-27. 
proliferation of the stencil image of Ai's likeness introduce the potential of the image to redistribute the sensible? As the image spread from backstreets to core commercial areas, the "street art campaign" gained a Wikipedia site, ricocheted in international media, and was featured on US National Public Radio. ${ }^{59}$ Its visual resonance, reproducing through analog effects, apparently forged a collective imaginary. In its stylistic resemblance to other iconic likenesses (Che Guevara, Mao Zedong, Barack Obama), it rhetorically cast the image as a cipher of history, projecting spatial interruption that compels comparison with groundbreaking historical events.

At this juncture, the problem is the reaction that says, "Look: Democracy!" The street-art campaign posted images of covert detention as the subject of daily-life, which is another kind of disappearance. It introduced to public space symbolic evidence of the absence of Hong Kong core values elsewhere in the nation space and, by posing the question, in a kind of exemplary rhetoric about a subject of tyranny, rendered thinkable where fear lies. News of the images did not appear in mainland China.

Ai's likeness also appeared projected on buildings, walls, and public infrastructure. One site was the face of the stone wall around the perimeter of the People's Liberation Army (PLA) headquarters in Hong Kong. In this instance, the scale of the projected image contributed to

${ }^{59}$ See Wikipedia, s.v. "Free Ai Weiwei Street Art Campaign," en.wikipedia.org/wiki/Free_Ai_Weiwei_Streetart_Campaign, and Louisa Lim, "Hong Kong Graffiti Challenges Chinese Artist's Arrest," NPR, 4 May 2011, www.npr.org/2011/05/04/135985475/hong-kong-graffiti-challenges-chinese-artists-arrest 
diminishing the relative size of PLA headquarters (fig. 8). Photographic records of the light projection or flash graffiti subsequently circulated on the internet. Ephemeral and fleeting, it left no physical trace. Nevertheless, the PLA raised objections and claimed "legal rights"' to act. ${ }^{60}$ The party state sees what was there and what is not there because the record of the image shows what it would control. A dialectical image transfers capacities "to destabilise classifications, disregard original intent, and disenable existing frames of meaning." ${ }^{61}$ The party state, sensitive about its monuments and totems, identifies and resists even symbolic challenges to its authority.

Artworks in public space characterize the independent arts sector in Hong Kong, which has never had a government culture policy or a museum of contemporary art. Absence of space for art in Hong Kong, in the conventional sense, contributes to a scene of multiple artist-run independent art spaces existing in relation to the absence/production of space.$^{62}$ In contrast to

${ }^{60}$ Quoted in James Pomfret, "Pro-Ai Graffiti in Hong Kong Sparks Warning by Chinese Army," Reuters, 29 Apr. 2011, www.reuters.com/article/us-china-grafitti-ai/pro-ai-graffiti-in-hong-kongsparks-warning-by-chinese-army-idUSTRE73T0D520110430. Tort and trespass law in Hong Kong would likely not uphold the notion.

${ }^{61}$ Susan Buck-Morss, “Obama and the Image,” Culture, Theory \& Critique 50, nos. 2-3 (2009): 154.

${ }^{62}$ See Cartier, "Culture and the City: Hong Kong, 1997-2007," China Review 8 (Spring 2008):

59-83. Public space is also the focus of civic concern. See also Yun-Chung Chen and Szeto, "Reclaiming Public Space Movement in Hong Kong: From Occupy Queen's Pier to the Umbrella 
modern art history, Rancière's space for redistribution of the sensible is not one in which temporal categories of art emerge. ${ }^{63}$ Not framed in a decontextualized history of modernity or postmodernity, art's politics hosts contending subjects, layered contextual sites and complex temporalities. Its spaces of disagreement in Hong Kong make apprehensible the politically unsayable that frames the aesthetics of politics in this fugitive time of the SAR.

\section{Nation Space, Culture, City}

The metaproblem that resists thinking about redistribution of the sensible in space-time is the territorial trap in social thought, in imaginaries of national boundaries, that renders space contained and static in state-to-state relations. Repetition of China, as if ever whole, rescores it. The notion that core values predominate uniformly across nation space adds to misapprehension. Party promotion of nationalism renews its potentials. The problem of the nation as container also appears in the world art system that collects art and projects its history in national frames. It also scales down to typecast cities as centers of traits; in historical urbanism the orthogenetic city of political power and aesthetic and ritual ideals contrasts with the heterogenetic city of cultural diversity linked to external economies. ${ }^{64}$ Dominated by a series of inland northern capitals,

Movement," in City Unsilenced: Urban Resistance and Public Space in the Age of Shrinking Democracy, ed. Jeffrey Hou and Sabine Knierbein (New York, 2017), pp. 69-82.

${ }^{63}$ See Rancière, Aesthetics and its Discontents, p. 25.

${ }^{64}$ See Robert Redfield and Milton B. Singer, "The Cultural Role of Cities," Economic Development and Cultural Change 3 (Oct. 1954): 53-73. 
China's civilizational history has othered the hybrid cities of the south. Recent proclamations from the core leader about "no more weird architecture" in urban aesthetics revive notions about Beijing as the guardian of essential Chineseness. ${ }^{65}$ In this historical discourse, the cultural-desert trope, as if a metonym of Hong Kong, is only one element of the narrative.

The institutional text that defines the Hong Kong SAR, The Basic Law, also represents conventional geopolitical space. After 2003, many Hong Kong artworks dealt explicitly with the text of The Basic Law and the power of discourse to inform, shape, and de/construct political realities. ${ }^{66}$ In 2005, the year of the Performance Art on the Move project, artist and scholar Wen Yau used a voice writer in a performance at Para/Site to translate Cantonese reading of the Basic Law into Mandarin or Putonghua, the national language. Even the phrase, Hong Kong Special Administrative Region Basic Law, emerged in a string of gibberish, "triangular-iron-selectprosthesis-idiotic-avowal” (鐵選取義肢䵑筋自白). ${ }^{67}$ The language of the nation-state and its regions do not align. The linguistic dissonance underscores that Cantonese is a language, not a dialect of Putonghua as it is portrayed by national ideals.

65 “习近平称 ‘不要搞奇奇怪怪的建筑” 获网民称赞” (Xi Jinping’s Statement “No More Weird Architecture” Praised by Netizens), 参考消息 (Reference News), 18 Oct. 2014, china.cankaoxiaoxi.com/2014/1018/532784.shtml

${ }^{66}$ See Cartier, "Power Plays," pp. 25-40.

${ }^{67}$ Wen Yau, TengSeWong/VoiceWriter Series, 23 Apr. 2005, www.wenyau.net/TengSeWong/onbasiclaw.html 
In July 2007 "Back to the Basic" opened at C\&G Artpartment. The exhibit's curatorial brief anticipated works drawing on personal understandings of The Basic Law. Leung performed "Basic Law is Burning" at the opening. She read a page of the Basic Law booklet into a viewer's ear then removed and burned the page and collected and presented the ashes. This intersubjective public act of private burning suggests the slow burn or erosion of the Basic Law—no Hong Kong representative had a seat at the table in its drafting — and book burning in Chinese history that would destroy the values of an era ${ }^{68}$ The spatial aesthetic of state documents represents territory contained.

The PRC's post-1978 cultural policy document, prepared for UNESCO, introduces culture as "an instrument to govern and educate the people." ${ }^{99}$ In the dialectic of contending values, this governmentalizing capacity and the state's understanding of culture as an arena of governmentality are counterposed to the absence in Hong Kong of the Chinese government's Ministry of Culture. Censorship of cultural events exemplifies relational politics. A notable rejection of aesthetic content occurred in 2011, in Beijing, when the debut of a new opera, $D r$. Sun Yat-sen, produced by Opera Hong Kong, for the centennial of the 1911 Revolution, was

${ }^{68}$ See Leung Po-shan, Basic Law is Burning in Back to the Basic, live performance at C\&G Artpartment, Hong Kong, 9 June 2007. Leung Po-shan also performed Public Act of Private Hearing: Book Burning in 2007 at the Queen's Pier; see Szeto, “Intra-local and Inter-local Sinophone," pp. 194-95.

${ }^{69}$ Bai Liu, Cultural Policy in the People's Republic of China: Letting a Hundred Flowers Blossom (Paris, 1983), p. 15. 
abruptly cancelled. Sun Yat-sen is revered inside and outside the PRC. But the opera's musical score, a variation on American minimalism, was judged "not politically serious enough" by the party committee of the National Center for the Performing Arts. ${ }^{70}$ It premiered in Hong Kong instead. In 2012 the relevant party committee censored or disallowed the famous Mao prints from appearing in the Beijing and Shanghai shows of "Andy Warhol: 15 Minutes Eternal.” The Hong Kong Art Museum installed the full exhibit including the multiple multicolored Mao likenesses. ${ }^{71}$ The appearance of these cultural works in Hong Kong, and their absence in the nation, reverses notions about a culture of disappearance. Space-time relations at stake between Hong Kong and mainland China represent collisions and generate interstices; politicization of aesthetics and aesthetics of politics cannot be entirely extricated from the historical legitimacy of propaganda and its uses in the PRC.

In 2011 debate erupted over the proposition that Hong Kong needs a government culture bureau. The proposal emerged in the run-up to the 2012 "election" of the Hong Kong Chief Executive, among what are called in Hong Kong "pro-Beijing" positions. ${ }^{72}$ Dialogue over the

${ }^{70}$ George Loomis, "Hong Kong, Not Beijing, Sees an Opera Laced with Revolutionary Zeal," New York Times, 18 Oct. 2011, www.nytimes.com/2011/10/19/arts/19iht-LOOMIS19.html ${ }^{71}$ See “Andy Warhol Mao Portraits Banned in China," The Telegraph, 20 Dec. 2012, www.telegraph.co.uk/culture/art/art-news/9757572/Andy-Warhol-Mao-portraits-banned-inChina.html

${ }^{72}$ Ming K. Chan, “The Challenges of ‘One Country, Two Systems’ Disequilibrium in China’s Hong Kong SAR, 1997-2017," Chinese Law and Government 50, no. 1 (2018): 4. 
proposal, documented in the media, floated names of potential directors of the proposed bureau; observers quickly noted their lack of requisite professional experience. ${ }^{73}$ In a published debate over whether Hong Kong needs a culture bureau, Oscar Ho Hing-kay, a professor at the Chinese University of Hong Kong, pointed to the incommensurabilities between Hong Kong core values and socialist core values that would impinge on the arts. "No," he replied, "if the bureau is in fact the 'Propaganda Office for Social and Cultural Harmony,' with the political missions of controlling cultural activities and undertaking patriotic or other forms of political propaganda." ${ }^{\prime 74}$ In the face of this less than opaque United Front activity, the outstanding sculpture in the 1 July 2012 march was a tank in a color bleeding to red: a pink tank on the march. On its side, large red characters 文化号 (wenhua hao) and The Cultural Bureau marked its function; it also embodied

${ }^{73}$ See Vivienne Chow AUTHOR: Yes this is the writer, "Critics Round on 'Outsider' Tipped to Run Culture Bureau,” South China Morning Post, 22 May 2012, p. 3.

74 "SCMP Debate," South China Morning Post, 7 May 2012 AUTHOR: Date confirmed in Newsbank, www.scmp.com/article/1000325/scmp-debate 
a history of PLA armored personnel carriers in public space including in Hong Kong. ${ }^{75}$ Wong manned the vehicle, periodically tossing into the air hundred million dollar bills that would buy loyalty to the bureaucracy (figs. 9a-9b). Wong's The Real Culture Bureau (2012), featuring the full-size pink tank, appeared in his 2015 exhibit, "Resisting Against Absurdity."

\section{The Production of Space}

Since the 1950s party state authority over the cultural sphere in China has included constructing (jianshe, 建设) and governing (zhili, 治理) cultural facilities (wenhua sheshi, 文化设施) including museums, libraries, and exhibition centers. The Ministry of Culture continues this practice in new forms including spectacular architecture. In Hong Kong, one of the highest density urban environments, dominance of the property sector has made space for art and culture

75 On 15 June 2012 PLA troop carriers appeared on commercial streets in Kowloon. Two days later the South China Morning Post identified the movements as "just an exercise" (Emily Tsang, "Military Movement 'Just an Exercise' - Officials Seek to Reassure Public Presence of PLA Trucks and APCs on City's Streets Was Routine," South China Morning Post, 17 June 2012, p. 5), while the 16 June edition of the Oriental Daily (東方日報) led with “解放軍增援 裝 甲車隊入城” (People’s Liberation Army Reinforcement Armored Vehicle Group Enters City) and “嚴防 7-1 失控 全港一 級戒備” (Take Strict Precautions Against 1 July Going Out of Control, All Hong Kong on Alert). Oriental Daily, 16 June 2012, orientaldaily.on.cc/cnt/news/20120616/00174_001.html 
subject to economic rationales. Absence of large-scale public space for art has compelled exhibits to adopt private commercial sites. The outstanding example is the exhibition of Pablo Picasso's Parade at the International Financial Centre (IFC). The Georges Pompidou Museum sent the $16 \times 10$ meter painting, the curtain for a 1917 theatrical performance, to Hong Kong to inaugurate the 2004-2005 "Year of France in China." Sun Hung Kai Properties, Hong Kong’s largest developer, was delighted to hang it in the atrium of its eighty-eighty story skyscraper next to the IFC Mall. The nineteen-day exhibit attracted two million viewers, over one quarter of the population (fig. 10). A phenomenon, its effects sustained ideas about public support for culture in the city. ${ }^{76}$

Hong Kong entered a new era in 1997 with a concept plan for a cultural district located on a forty-square-kilometer reclamation on the West Kowloon waterfront. But the initial plan would assign construction and administration of the built environment, including arts administration, to property developers. It collapsed under scrutiny in 2006 and was tabled for revision. Intensifying the public expectation of transparency and upholding Hong Kong core values squarely challenged Hong Kong government's historical alliance with property developers. ${ }^{77}$ As one journalist observed, "the government who initiated this project, the property

76 "New Model Needed for Art Museums," South China Morning Post, 12 Sept. 2006, www.scmp.com/article/563690/new-model-needed-art-museums

${ }^{77}$ See Brian C. H. Fong, “State-Society Conflicts under Hong Kong's Hybrid Regime: Governing Coalition Building and Civil Society Challenges," Asian Survey 53 (Sept./Oct. 2013): $854-82$. 
developers who are interested in the project, and the public for whom this project is built all know very little — if anything — about art and culture." 78 Critique of the West Kowloon planning process generated widespread public discussion about what is culture in the city-from absence to subject, culture went public. ${ }^{79}$

The production of space in the city abstracts new spaces from historic places through strategic plans and politicized projects to generate economic rents. Struggles ensue over meanings and impacts: "What is an ideology without a space to which it refers," writes Henri Lefebvre, "a space which it describes, whose vocabulary and links it makes use of, and whose code it embodies?" "Big-city space is in no way analogous to the space of a company town —and it is for this reason that a city cannot be run on such a model, no matter how big a company one envisages. ... Whereas businesses tend towards a totalitarian form of social organization, authoritarian and prone to fascism, urban conditions, either despite or by virtue of violence, tend to uphold at least a measure of democracy." 80

${ }^{78}$ Kevin Kwong, "East Wing West Wing 4-West Kowloon Side Story,” South China Morning Post, 26 July 2005, p. 6.

${ }^{79}$ See Eliza W. Y. Lee et al., "The West Kowloon Cultural District Project," in Public Policy Making in Hong Kong: Civic Engagement and State-Society Relations in a Semi-Democracy (New York, 2013), pp. 54-68.

${ }^{80}$ Henri Lefebvre, The Production of Space, trans. Donald Nicholson-Smith (Cambridge, Mass., 1991), pp. 44, 319. 
The production of space in mainland China conspicuously reveals vast new scales of transformation through construction of hundreds of new cities. ${ }^{81}$ At this scale - the city on a new horizon - the West Kowloon Cultural District reemerged in the space-time of national territory. In 2008 the Hong Kong government announced that West Kowloon would also serve as the terminus of the Hong Kong-Shenzhen-Guangzhou Express Rail or Express Rail. "Why is the station so big?" was one question raised by the public. The functional answer was that it would serve national high-speed trains, making space for arrival of the "Harmony Express" (hexie hao, 和谐号). ${ }^{82}$ The location of its lately announced terminus, astride the new cultural district, introduced questions without credible answers because bringing the train into the Kowloon waterfront more than doubled the cost of the project. $^{83}$

${ }^{81}$ See Cartier, "Territorial Urbanization and the Party-State in China," Territory, Politics, Governance 3, no. 3 (2015): 294-320.

${ }^{82}$ Evan Osnos, “Boss Rail,” The New Yorker, 15 Oct. 2012, www.newyorker.com/magazine/2012/10/22/boss-rail

${ }^{83}$ The alternative plan linked the Express Rail to existing transportation infrastructure outside the urban core; see New XRL Expert Group, “[Hong Kong Interchange Option]: A Cheaper, Faster and Better Express Rail Link,” (Hong Kong, 2009), p. 9, www.procommons.org.hk/wpcontent/uploads/2009/10/Express_Rail_Link_Report.pdf 
Presented to the Hong Kong public as an intercity express link, the government's publicity campaign dissembled, using factitious journeys and roundabout math. ${ }^{84}$ (It would not halve the one hundred minute rail journey to Guangzhou, capital of the adjacent province in mainland China because the railway's new Guangzhou South station is twenty kilometers southeast and forty-five minutes by subway from Guangzhou.) Its illusory geography evoked an inventive truth and apparition of its larger identity: the southernmost portion of the national trunk line from Beijing. Its globally unprecedented cost per kilometer is owed to its form and function - a twenty-six kilometer tunnel direct from the Hong Kong harbor front to mainland China. Its construction claims maximal capital and technological power, wrenching open and bending to its will ancient earth for the tunnel that will realize another national ambition and infrastructural achievement. Limited public disclosure about the project, combined with unprecedented public cost, underscored the railway's representative power. The 1 July 2009 march became a context for its contestation.

Circulating in the crowd at the start of the march was an information broadsheet with a bold headline: 你知道广深港高铁吗? (Do you know about the Guangzhou-Shenzhen-Hong Kong Express Rail?) Marchers’ signs included 假民主, 真獨裁 (false democracy, real dictatorship). Along the route of the march, under the banner "Oppose the Express Rail," a performance led by Yuenjie Maru focused not on the totality of the project but its destruction of

${ }^{84}$ See Chloe Lai, "Railroaded into the Front Lines," South China Morning Post, 7 Mar. 2010, www.scmp.com/article/707899/railroaded-front-lines 
a village for an emergency exit, the only intermediate facility on the Hong Kong alignment. Yuenjie plays a dirge and wears a birdcage, symbolizing Hong Kong's kept state (fig. 11a). A woman stands by holding an umbrella, marked 拆 (chai, to tear down), the one-word notice which appears on buildings slated for demolition in the Mainland. A symbolic field with cabbages, wrapped in burning paper, suggests a ritual. A man lies on the ground, as if cast aside, a large tire in red fabric on his body and rail tracks across his chest (fig. 11b). The aesthetics of the performance's politics, claiming a moral order on behalf of elderly whose homes were destroyed, portrayed the part of those who have no part, the potential of "a unity ... that superimposes the effectiveness of a part of those who have no part on the reckoning of society's parties" ( $D$, p. 99). Civil action against the Express Rail, in the face of declining influence of elites among the people, contributed to revealing a governing crisis.

In 2012, the then-forthcoming museum of contemporary art at West Kowloon named M+ initiated advance mobile programs to explore "different possibilities of engaging the public without the presence of a building." ${ }^{\circ 5}$ (Herzog \& De Meuron won the design competition for the museum in 2013.) The first exhibition in a series, "Mobile M+: Yau Ma Tei," asked artists to "(re)imagine the city's history and stories by interpreting "narrative"” through installation works. ${ }^{86}$ To Defend Core Values Is the Core of Core Values, by Kwan Sheung Chi and Wong Wai Yin, invited the public to submit their views on the meaning of Hong Kong values.

85 “Mobile M+: Yau Ma Tei,” 2012, www.westkowloon.hk/en/whats-on/past-events/mobile-myau-ma-tei

${ }^{86}$ Ibid. 
Positioned in relation to their specially made coin, imprinted with "Hong Kong core values," the work juxtaposed liberal core values of rights and freedoms with such Hong Kong values as money (fig. 12). Does the image represent the future in Hong Kong's hands?

By 2013 the collection plan of M+ had changed—from a museum of design, moving image, popular culture, and visual art, with a strong Hong Kong emphasis, to a museum of art, design, architecture and the moving image. The revision unprecedentedly prioritized "art" and removed popular culture. The new emphasis on architecture left concerns unassuaged: "The change has some ulterior motive in order to remove 'Popular Culture' from the four groupings. The change is no trivial matter at all." ${ }^{\prime 87}$ The apparent redefinition of the museum's mission, in absence of public consultation, sowed mistrust. In 2012 the M+ administration acquired a large portion of the Uli Sigg collection of late twentieth-century Chinese art. Many of its works would be subject to the Culture censorate on the Mainland. Housed in Hong Kong, the collection represents the contradiction between socialist core values and Hong Kong core values; its contents reflect an art history of China removed from Hong Kong, while in the PRC only under

${ }^{87}$ Tse Muse Anita, "M+ Mistaking 'Museum for Visual Culture' for Museum of Art," Cultural Vision (文化視野) 2 (2013): 48 Author: This source is a print journal which was published for only three years (2011-13) in Hong Kong. It is held at the Asia Art Archive, Hong Kong, which the link, deleted now, shows. 
Hong Kong core values can its complement of works be reliably shown. Now the critique of "a colonised art museum" precedes its opening. ${ }^{88}$

\section{Coda}

"Art exists," writes Rancière, "when one can make a people, a society, an age, taken at a certain moment in the development of its collective life, its subject." ${ }^{89}$ In an interview about the idea of emancipation of the spectator, Rancière finds possibilities in "precisely the creation of places where works of art or performances of art are no longer restrained to a specific audience or a specific function." Two hundred years ago, before it became a space for legitimation of art in the national frame, the museum was one such place. Now, "what allows the spectator to create his or her own poem is the existence of places and spectacles whose status remains more or less indeterminate. ${ }^{, 90}$ In public space in Hong Kong, where the possible of the community redefines its interests and gains its voice, street performance, discrete and immediate, reckons with a city experiencing hurtling change. Its aesthetics of politics, its dissensual commitments, portray

${ }^{88}$ Ibid., p. 45. Debate escalated after discovery that the reorganization reduced Hong Kong content.

${ }^{89}$ Rancière, Aisthesis: Scenes from the Aesthetic Regime of Art, trans. Zakir Paul (New York, 2013), p. 14.

${ }^{90}$ Rancière, “Aesthetics and Politics Revisited: An Interview with Jacques Rancière," interview by Gavin Arnall, Laura Gandolfi, and Enea Zaramella, Critical Inquiry 38 (Winter 2012): 292, 293. 
complex issues in tactical forms, out of place, asynchronic, juxtaposed, negotiating the sensorium of the city.

Works that contribute to redistributing the sensible, signaling possibilities for community, take multiple forms. The image's capacity to challenge state frames of reference arguably heightens in the gaps between contending values. Responding to the notion of the impact of propaganda, Ban Wang turns the relationship around and asks: What did people do to propaganda? Punning is one response in a practice of wordplay. Its aesthetics contribute rhetorical capacity to the evaluation of political positions on the spectrum of postdemocracy. Tactical redistributions arguably emerge especially where state power is attuned to defining and designing the message while scrutinizing and censoring divergence from its positions. The state's (in)comprehension of dissensual aesthetics infuses the potential of a politics to redistribute the police order that seeks to keep people in their place. Like comedic aesthetics in troubled times, joking in Hong Kong is consistent with the dynamics of its core values.

The relationship between infrastructure and postdemocracy is not immediately apparent. Heroic railway achievements would seem to belong to another era. Yet in precincts of culture in the city, China holds fast to the privileges of the nation space, including that of governing Culture within explicit territories defined in relation to national infrastructure. Development of high-speed rail in relation to a large-scale cultural center claims the SAR's capacity to capitalize infrastructure for national modernization and territorial consolidation. ${ }^{91}$ The site of the rail

\footnotetext{
${ }^{91}$ New protests against funding the Express Rail erupted in 2015 in response to delays and cost overruns. An editorial in the South China Morning Post sought to support the project: "Hong
} 
terminus positions the cultural district at the juncture of a nonstop journey that is always bound for a border within. Its space-time convergence pivots the city toward its northern hinterland. Its aesthetic of centrality, connecting a core of Hong Kong to the core of the capital, demonstrates the will of the state to design the future of the city in the nation. Its fundamental border-crossing capacity emerged in 2017 when the Chinese central government approved placement of mainland police and customs officials, enforcing laws of mainland China, in the Hong Kong terminus. $^{92}$

"Politics," on Rancière's terms, "occurs when those who 'have no' time take the time necessary to front up as inhabitants of a common space and demonstrate that their mouths really do emit speech capable of making pronouncements," becoming "heard as speakers" where they had once been "perceived as mere noisy animals." 93 Through aesthetic expressions—-fluid, improvisational and quick-witted — and with appeals to a greater humanism, the people (the

Kong will remain isolated from the national grid, progress on the West Kowloon arts district will be hampered and our city's reputation for quickly constructing world-class infrastructure tested" (“Over Budget and Behind Schedule: Hong Kong Must Now Make Haste on High-Speed Rail Link to Guangzhou," South China Morning Post, 15 Sept. 2015, www.scmp.com/comment/insight-opinion/article/1861235/over-budget-and-behind-schedulehong-kong-must-now-make).

92 See Dennis Kwok, "Why Co-location Arrangement Is Unconstitutional," ejinsight, 25 July 2017, www.ejinsight.com/20170725-why-co-location-arrangement-is-unconstitutional/ ${ }^{93}$ Rancière, Aesthetics and its Discontents, pp. 24, 25. 
demos) express exemplary values in symbolic works that negotiate uncertainties of advancing illiberalism. They interpret where words fail. Their tactics contribute to knitting elements of community into a political fabric. Their greater issue is consensus democracy that is also harmonious society in a state that evacuates disputes of the people, disappearing "any gap between a party to a dispute and a part of society" or the potential of politics $(D$, p. 102).

In 2014 the Umbrella Movement in Hong Kong, named after a daily life accessory, was widely portrayed in the international media as an unexpected event. The spectacle of itunfurling commitment in public space, over days, weeks, and months-magnetized new audiences. Its chroniclers, seeking to account for sheer creativity, documented links between protest and art. ${ }^{94}$ Writing in The New Yorker, Christopher Beam explained he went to Art Basel Hong Kong in 2015 "expecting to see political messages, especially given that it had only been a couple of months since the pro-democracy Occupy Central protests had gripped Hong Kong." 95 At the commercial art fair he found little. (By 2012 Hong Kong had become the third largest art auction center after London and New York.) In Hong Kong, Beam asked artists from Beijing why they were not working on politics. He did not interview artists working in Hong Kong or

${ }^{94}$ See, for example, Sampson Wong, "Crowd Creations: Interpreting Occupy Art in Hong Kong's Umbrella Movement," in Art and the City: Worlding the Discussion through a Critical Artscape, ed. Jason Luger and Julie Ren (New York, 2017), pp. 194-206.

${ }^{95}$ Christopher Beam, "Beyond Ai Weiwei: How China’s Artists Handle Politics (or Avoid Them)," The New Yorker, 27 Mar. 2015, www.newyorker.com/news/news-desk/ai-weiweiproblem-political-art-china 
gauge the spatiotemporal rhythms of Hong Kong's urban scene. The absence of political substance returns to a version of the culture of disappearance: the problem of not seeing - on two fronts-what was already there.

While this writing was in production in 2019 the Anti-Extradition Bill Protest Movement began in Hong Kong, becoming the “Revolution of Our Times” (shidai geming, 时代革命). ${ }^{96}$ The extradition bill, inviting recognition of united front work, also pointed to the 2018 amalgamation of government departments that oversee ethnic policy, religion, and overseas Chinese affairs with the United Front Work Department. ${ }^{97}$ Its expansion from party organ to government apparatus would rationalize its activity, narrowing by governing what it knows in other terms Rancière's partition of the sensible. Priorities registered in late July when, subsequent to the Yuen Long Incident, the national emblem of the People's Republic on the façade of the Liaison Office was enclosed in a plexiglass box. "Safety first for national emblem" read a discerning Hong Kong headline. ${ }^{98}$

${ }^{96}$ See Barmé, "Restore Hong Kong, Revolution of Our Times," China Heritage, 6 Aug. 2019, chinaheritage.net/journal/restoring-hong-kong-revolution-of-our-times/

${ }^{97}$ See Gerry Groot, "The Rise and Rise of the United Front Work Department under Xi," China Brief, 24 Apr. 2018, jamestown.org/program/the-rise-and-rise-of-the-united-front-workdepartment-under-xi/ ${ }^{98}$ See "Safety First for National Emblem,” The Standard, 29 July 2019, www.thestandard.com.hk/section-news.php?id=210055\&sid=21 
FIGURE 1. "Socialist Core Values," Billboard (Chinese Communist Party, 2012)

FIGURE 2. "Cultivate and Practice Socialist Core Values," Poster (Chinese Communist Party, 2012)

FIGURE 3. "How the CCP Rules," Infographic (East Asia Center, Harvard University, 2017).

FIGURE 4a and 4b. "Who's Afraid of Ai Weiwei" Stencil and Paint, Chin Tangerine (2011).

FIGURE 5. “Grass Mud Horse,” Sculpture, Kacey Wong (2011)

FIGURE 6. "Wedding Engagement," Performance, Cheng Yee-man and Clara Cheung (2004)

FIGURE 7. “我恨这个党 I Hate this Party” in “Among Others..., Banner, Para/Site Art Space. (2007) (Photograph by the Author)

FIGURE 8. "Whose Afraid of Ai Weiwei?" Flash Graffiti, Cpak Ming. (2011)

FIGURE 9a and 9b. “The Real Culture Bureau,” \$100,000,000 Dollar Bill, Kacey Wong (2012)

FIGURE 10. "Parade," Pablo Picasso (1917), Installed at the International Financial Centre (South China Morning Post, 2004)

FIGURE 11a and 11b. “Oppose the Express Rail,” Performance, Yuenjie Maru (2009) (Photographs by the Author)

FIGURE 12. "To Defend Core Values is the Core of Core Values," Photograph and Metal Work, Kwan Sheung Chi and Wong Wai Yin. (2012)

[bio] Carolyn Cartier is Professor of Human Geography and China Studies at the University of Technology Sydney. In 2004-05 she was a Fulbright Fellow in Hong Kong, and was a founding member of the UTS China Research Centre, in 2009, when she joined the Australian academy. 
Her current work in progress includes a book project, City Space: Theory, Reality and the Administrative Divisions in China, and an edited collection, The Urban Process in China: State Power, Territorial Economy, and the Future of the City. 